University of Nebraska - Lincoln

DigitalCommons@University of Nebraska - Lincoln

USDA National Wildlife Research Center - Staff Publications
U.S. Department of Agriculture: Animal and Plant Health Inspection Service

$1-1-2006$

\title{
Potential predators of an invasive frog (Eleutherodactylus coqui) in Hawaiian forests
}

\author{
Karen H. Beard \\ Utah State University, karen.beard@usu.edu \\ William C. Pitt \\ USDA/APHIS/WS/National Wildlife Research Center
}

Follow this and additional works at: https://digitalcommons.unl.edu/icwdm_usdanwrc

Part of the Environmental Sciences Commons

Beard, Karen H. and Pitt, William C., "Potential predators of an invasive frog (Eleutherodactylus coqui) in Hawaiian forests" (2006). USDA National Wildlife Research Center - Staff Publications. 107.

https://digitalcommons.unl.edu/icwdm_usdanwrc/107

This Article is brought to you for free and open access by the U.S. Department of Agriculture: Animal and Plant Health Inspection Service at DigitalCommons@University of Nebraska - Lincoln. It has been accepted for inclusion in USDA National Wildlife Research Center - Staff Publications by an authorized administrator of DigitalCommons@University of Nebraska - Lincoln. 


\title{
Potential predators of an invasive frog (Eleutherodactylus coqui) in Hawaiian forests
}

\author{
Karen H. Beard*1 and William C. Pitt $\dagger$ \\ * Department of Forest, Range and Wildlife Sciences and Ecology Center, Utah State University, Logan, UT 84322-5230, USA \\ $\dagger$ USDA/APHIS/WS/National Wildlife Research Center, Hilo Field Station, Hilo, HI 96721, USA \\ (Accepted 8 December 2005)
}

Key Words: amphibian, Bufo marinus, introduced mammals, invasive, Herpestes javanicus, Rattus exulans, Rattus rattus, stomach content

In Hawaii, where there are no native reptiles or amphibians, 27 species of reptiles and amphibians have established (Kraus 2003); however, few have been studied to determine their ecological impacts. For example, little is known about the impacts of the Puerto Rican frog, Eleutherodactylus coqui Thomas, that recently invaded (late 1980s) (Kraus et al. 1999), and has established on all four main Hawaiian Islands (Kraus \& Campbell 2002). However, there are likely to be consequences because E. coqui can attain high densities (20 570 frogs ha $^{-1}$ on average in Puerto Rico) and consume large quantities of invertebrates (114000 prey items ha ${ }^{-1}$ per night on average in Puerto Rico) (Stewart \& Woolbright 1996).

One potential consequence of the invasion is that E. coqui could indirectly reduce endemic prey by suddenly increasing population sizes of introduced predators (Courchamp et al. 2000). More specifically, Kraus et al. (1999) proposed that E. coqui may indirectly contribute to endemic bird declines by bolstering populations of nonnative bird predators, such as rats (e.g. black (Rattus rattus L.) and Polynesian (R. exulans Peale)) and the small Indian mongoose (Herpestes javanicus E. Geoffroy Saint-Hilaire). In this study, we investigated whether $E$. coqui serves as a food source for introduced predators, R. rattus, R. exulans and $H$. javanicus, and the cane toad (Bufo marinus L.), in an area with high $E$. coqui densities.

Research was conducted in Lava Tree State Park (LTSP; $\mathrm{N} 19^{\circ} 28.99^{\prime} \mathrm{W} 154^{\circ} 54.20^{\prime}$; $181 \mathrm{~m}$ asl) located on the eastern side of the Island of Hawaii. The park is located on 200-750 y old a'a type lava rock, and has a mean annual temperature of $23^{\circ} \mathrm{C}$ and mean annual precipitation of $2500 \mathrm{~mm}$ (Giambelluca et al. 1996). Falcataria moluccana (Miquel) Barneby \& Grimes, Cecropia obtusifolia Bertol. and Metrosideros polymorpha Gaud. dominate

\footnotetext{
${ }^{1}$ Corresponding author. Email: karen.beard@usu.edu
}

the forest overstorey, and Clidemia hirta (L.) D. Don, Psidium cattleianum Sabine and Melastoma candidum D. Don dominate the understorey. The E. coqui population at LTSP was established in 1996, and was determined to have a density of 55000 individuals $\mathrm{ha}^{-1}$ in August 2004 (Beard \& Pitt 2005).

The sampling area for rats and mongooses consisted of a trapping web with an effective trapping area of $c$. 2 ha. The web was bordered by a trail on two sides and Highway 132 on another side. The web contained sixteen 80-m transects radiating from a central point. Eight traps were placed along each transect at 10-m intervals. Every other transect had eight Tomahawk live traps or eight snap traps for a total of 128 traps.

Removal trapping was conducted from 10-16 June 2004 (period 1), from 2-14 January 2005 (period 2) and from 27 January-20 February 2005 (period 3). Sampling periods were intended to capture seasonal differences (Sugihara 1997). Traps were left open during sampling periods and checked twice daily, starting at 08h00 and 19h00. Traps were baited with shredded coconut and/or fish emulsion. Specimens trapped in Tomahawk traps were taken back to the laboratory and euthanized. All carcasses were frozen for later examination.

We used regression-based depletion estimates to estimate the population size $(\hat{N})$ of mammal species for each sampling period (Krebs 1999). Data were pooled across days into four sampling points for each sampling period. For some sampling periods for some species, it was not possible to fit a depletion model; hence these sampling periods were excluded from the mean. Standard deviations (SD) were calculated across sampling periods not around values of $\hat{N}$. Density was then estimated by dividing population size by area sampled.

In August 2004, we established a $100 \times 100-m$ plot within the trapping web to collect $B$. marinus. For five nights, starting at $21 \mathrm{~h} 00$, transects within the plot were 
searched for toads for a total of $100 \mathrm{~min}$ by three researchers with headlamps. Toads were taken back to the laboratory and euthanized. Carcasses were stored in $70 \%$ ethanol for later examination.

For each animal collected, the entire digestive tract (oesophagus to colon) was removed and contents were suspended in a $5 \%$ buffered formalin solution. Contents were then washed with distilled water, run through a 2 -mm sieve, and dried for $24 \mathrm{~h}$ at $35^{\circ} \mathrm{C}$. For each individual, dried samples were dissected under a microscope and contents were separated into broad categories (plant, invertebrate (to scientific order where possible), avian, amphibian, reptilian or mammalian) and weighed.

We used undigested subadult and adult E. coqui and B. marinus skeletons to identify digested frogs, using bone size and unique bone structures, such as urostyles, ilia and skulls. No other frogs were observed in the study area. Avian items were identified by the presence of feathers and unique bones, such as sterna or mandibles; mammalian parts were identified by the presence of hair; and the reptilian and Lepidoptera larvae samples were identified by their skin.

During $33 \mathrm{~d}$ (2112 trap-days), a total of 46 rats and $22 \mathrm{H}$. javanicus was collected. During sampling period $1,3 \mathrm{R}$. exulans, $14 \mathrm{R}$. rattus and $10 \mathrm{H}$. javanicus were collected. During period 2, 6 R. exulans, 4 R. rattus, and $8 \mathrm{H}$. javanicus were collected, and during period 3, 16 R. exulans, 1 R. rattus, and $4 \mathrm{H}$. javanicus were collected. Trapped R. exulans measured $274 \pm 18 \mathrm{~mm}$ (mean \pm SD) total length and $143 \pm 8 \mathrm{~mm}$ in tail length. Trapped $R$. rattus measured $377 \pm 39 \mathrm{~mm}$ total length and $208 \pm$ $16 \mathrm{~mm}$ in tail length. For both species, the sex ratio was biased towards males (1:0.6). Trapped mongooses measured $531 \pm 39 \mathrm{~mm}$ total length and $235 \pm 26 \mathrm{~mm}$ in tail length. The sex ratio was biased towards females (1:2.1). We estimated that there were $5.0 \pm 3.5$ R. exulans $\mathrm{ha}^{-1}, 3.6$ R. rattus ha ${ }^{-1}$ and $4.7 \pm 1.9 \mathrm{H}$. javanicus $\mathrm{ha}^{-1}$. We collected 27 B. marinus with a mean SVL of $80 \pm$ $16 \mathrm{~mm}$ and a sex ratio biased towards females (1:0.4).

Kraus et al. (1999) proposed that rats could be predators of E. coqui in Hawaii. This appeared likely because rats are nocturnal and arboreal, which means that they are able to actively hunt E. coqui foraging on leaves and trunks. However, we found that not one rat consumed E. coqui in an area infested with a dense E. coqui population (Figure 1). Rather, we found that rats mostly consumed plant material (fruits). Thus, our data suggest that E. coqui is unlikely to bolster these rat populations.

Much of the literature on the diet of $R$. rattus in Puerto Rico describes preferences for plant materials (MunizMelendez 1978, Sastre-De Jesus 1979, Weinbren et al. 1970). A review of the diet of $R$. rattus in the wet forests of El Verde only described plant material, despite an E. coqui density of $20000 \mathrm{ha}^{-1}$ (Willig \& Gannon 1996), although there has been personal observation of E. coqui consumption by R. rattus in El Verde (Stewart \&

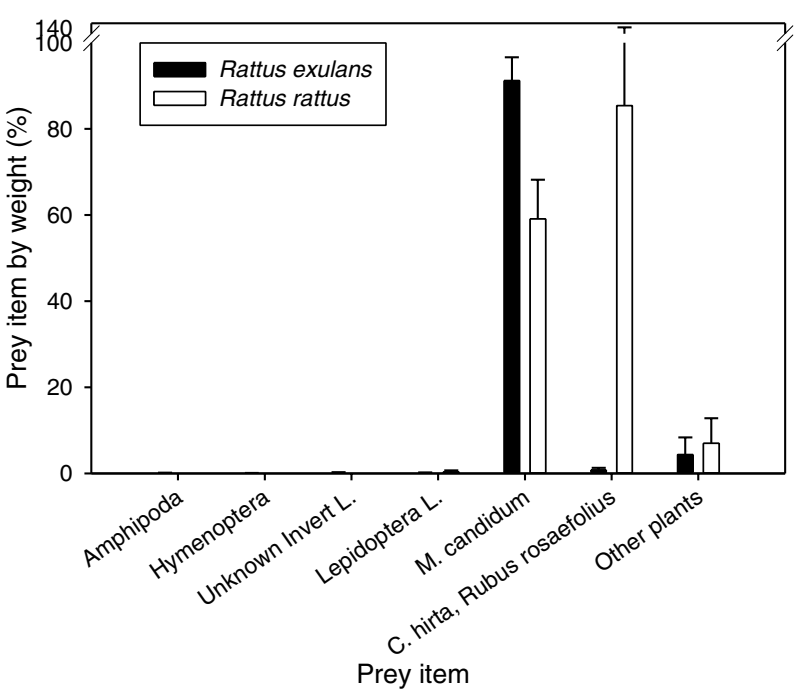

Figure 1. Per cent of prey items by weight ( \pm SE) for Rattus exulans and R. rattus from Lava Tree State Park, Island of Hawaii $(\mathrm{N}=25$ and $\mathrm{N}=$ 19 , respectively). invert. $=$ invertebrate, $\mathrm{L} .=$ larvae.

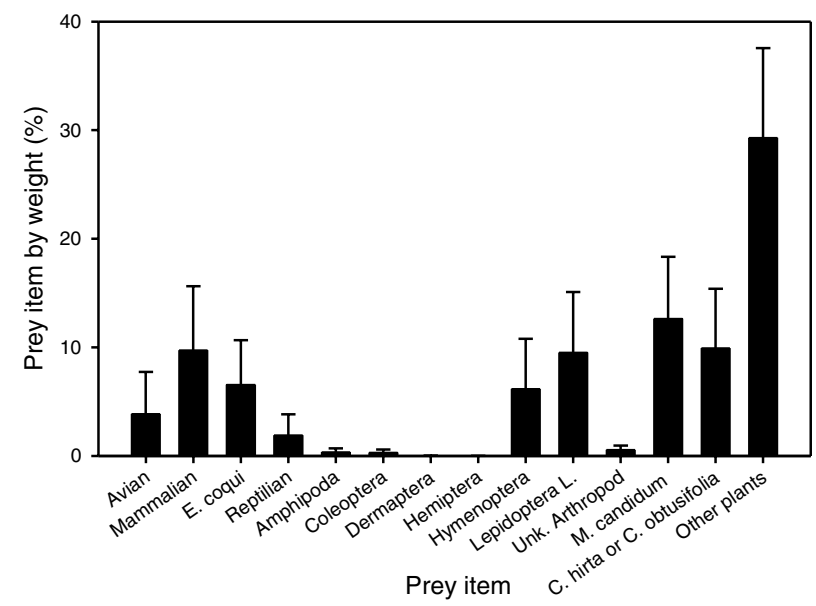

Figure 2. Per cent of prey items by weight ( \pm SE) for Herpestes javanicus from Lava Tree State Park, Island of Hawaii $(\mathrm{N}=22)$ L. = larvae, unk. $=$ unknown.

Woolbright 1996). In summary, there are few data from either location suggesting that $E$. coqui will constitute a large proportion of rat diets.

Kraus et al. (1999) proposed that mongooses could consume E. coqui in Hawaii. We found that, even though mongooses are diurnal and reportedly poor climbers, E. coqui constituted $6.6 \pm 19.2 \%$ of their prey items by weight (Figure 2) and three mongooses (14\%) had E. coqui bones in their digestive tracts. We found that one mongoose consumed $14 \mathrm{E}$. coqui and two others each consumed one E. coqui. We expect that mongooses consume E. coqui opportunistically in leaf litter or rocks.

Assuming digestive tract contents represent a day of feeding, the results translate to an average of 0.73 E. coqui consumed per mongoose $\mathrm{d}^{-1}$. Using our estimate of $4.7 \mathrm{H}$. javanicus $\mathrm{ha}^{-1}$, this converts to a consumption 
rate of 1240 E. coqui ha $\mathrm{h}^{-1} \mathrm{y}^{-1}$. This may impact this E. coqui population, which is estimated to recruit over 30000 E. coqui ha ${ }^{-1} \mathrm{y}^{-1}$ (assuming stable populations and using survivorship estimates from Stewart \& Woolbright 1996). However, it is difficult from these results alone to determine whether E. coqui is influencing this mongoose population.

At the time of sampling, E. coqui and H. javanicus had only co-existed in this location for $8 \mathrm{y}$. It may be that E. coqui will become an increasingly important component of mongoose diets over time. However, data from Puerto Rico, where E. coqui and H. javanicus have been co-existing for over $100 \mathrm{y}$ (Wadsworth 1949), also suggest that $E$. coqui represents a small percentage of mongoose diets. Pimentel (1955) found that Eleutherodactylus spp. constituted $1 \%$ of prey items by volume ( $\mathrm{N}=56$ mongooses), whereas Vilella (1998) found that Eleutherodactylus spp. were only consumed by $2(11 \%)$ of the 18 mongooses examined.

We thought that $B$. marinus may be a predator of $E$. coqui, but not one of the B. marinus examined consumed E. coqui. Of food items found in B. marinus, $40 \%$ by weight was plant material, which mostly consisted of $F$. moluccana leaves and bark. Of the animal items found, the large majority by weight consisted of Coleoptera (17.4\%), Diplopoda (22.8\%), Gastropoda (36.5\%) and Lepidoptera larvae $(9.6 \%)$. No other order made up greater than $5 \%$ of the weight of animal items consumed. Similarly, $B$. marinus has not been found to consume E. coqui in Puerto Rico ( $\mathrm{N}=301$ toads) (Dexter 1932). It does not appear likely that $E$. coqui will bolster populations of B. marinus in Hawaii. Rather, the long-term effect of these two species on each other may be through competition for resources (for preliminary E. coqui diet data in Hawaii see Beard \& Pitt 2005) or the spread of disease (Beard \& O'Neill 2005).

We found that research on potential predators of an invasive species in its native range informed the extent of predation by these species in an introduced range. Because the hypothesis that $E$. coqui may bolster predator populations in Hawaii has important implications, we suggest further research be conducted on the topic. First, it would be important to determine if densities of potential predators respond to changes in E. coqui densities. It would also be important to determine if there is evidence of sustained use of $E$. coqui by potential predators. Finally, studies should investigate whether at risk endemic populations show reduced survival in the presence of E. coqui.

\section{ACKNOWLEDGEMENTS}

Funding was provided by the Jack Berryman Institute, U.S. Fish and Wildlife Service, and Hawaii Invasive Species Council. We thank Wildlife Services Operation Unit and R. McGuire for field assistance, D. Grant for laboratory assistance, P. Budy for statistical assistance, and R. Sugihara for help identifying seeds.

\section{LITERATURE CITED}

BEARD, K. H. \& O'NEILL, E. M. 2005. Infection of an invasive frog Eleutherodactylus coqui by the chytrid fungus Batrachochytrium dendrobatidis in Hawaii. Biological Conservation 126:591-595.

BEARD, K. H. \& PITT, W. C. 2005. Ecological consequences of the coqui frog invasion in Hawaii. Diversity and Distributions 11:427-433.

COURCHAMP, F., LANGLAIS, M. \& SUGIHARA, G. 2000. Rabbits killing birds: modelling the hyperpredation process. Journal of Animal Ecology 69:154-164.

DEXTER, R. R. 1932. The food habits of the imported toad Bufo marinus in the sugar cane sections of Puerto Rico. Bulletin International Society of Sugar Cane Technology 74:1-6.

GIAMBELLUCA, T. W., NULLET, D. \& SCHROEDER, T. A. 1996. Rainfall atlas of Hawaii. University of Hawaii, Honolulu. 267 pp.

KRAUS, F. 2003. Invasion pathways of terrestrial vertebrates. Pp. 6892 in Ruiz, G. M. \& Carlton, J. T. (eds). Invasive species: vectors and management strategies. Island Press, Washington, DC.

KRAUS, F. \& CAMPBELL, E. W. 2002. Human-mediated escalation of a formerly eradicable problem: the invasion of Caribbean frogs in the Hawaiian Islands. Biological Invasions 4:327-332.

KRAUS, F., CAMPBELL, E. W., ALLISON, A. \& PRATT, T. 1999. Eleutherodactylus frog introductions to Hawaii. Herpetological Review 30:21-25.

KREBS, C. J. 1999. Ecological methodology. Addison-Wesley Educational Publishers, Menlo Park. 620 pp.

MUNIZ-MELENDEZ, E. 1978. Demographic analysis of the life history of Inga vera subspecies vera. M.S. Thesis, University of Tennessee, Knoxville.

PIMENTEL, D. 1955. Biology of the Indian mongoose in Puerto Rico. Journal of Mammalogy 36:62-68.

SASTRE-DE JESUS, I. 1979. Ecological life cycle of Buchenavia capitat (Vahl) Eichl., a late secondary successional species in the rain forest of Puerto Rico. M.S. Thesis, University of Tennessee, Knoxville.

STEWART, M. M. \& WOOLBRIGHT, L. L. 1996. Amphibians. Pp. 363398 in Reagan, D. P. \& Waide, R. B. (eds). The food web of a tropical rain forest. University of Chicago Press, Chicago.

SUGIHARA, R. T. 1997. Abundance and diets of rats in two native Hawaiian forests. Pacific Science 51:189-198.

VILELLA, F. J. 1998. Biology of the mongoose (Herpestes javanicus) in a rain forest in Puerto Rico. Biotropica 30:120-125.

WADSWORTH, F. H. 1949. The development of forest land resources of the Luquillo Mountains, Puerto Rico. Ph.D. Dissertation, University of Michigan, Ann Arbor.

WEINBREN, M. P., WEINBREN, B. M., JACKSON, W. B. \& VILLELLA, J. B. 1970. Studies on the roof rat (Rattus rattus) in the El Verde forest. Pp. 169-181 in Odum, H. T. \& Pigeon, R. F. (eds). A tropical rain forest: a study of irradiation and ecology at El Verde, Puerto Rico. N.T.I.S., Springfield.

WILLIG, M. R. \& GANNON, M. R. 1996. Mammals. Pp. 400-431 in Reagan, D. P. \& Waide, R. B. (eds). The food web of a tropical rain forest. University of Chicago Press, Chicago. 